\title{
TEACHERS' SOCIAL REPRESENTATIONS ON DRUG USE IN A SECONDARY SCHOOL
}

\author{
Jussara Gue Martini ${ }^{1}$ \\ Antonia Regina Ferreira Furegato ${ }^{2}$
}

Gue Martini J, Furegato ARF. Teachers' social representations on drug use in a secondary school. Rev Latino-am Enfermagem 2008 maio-junho; 16(especial):601-06

Increased concern regarding drug abuse among adolescents contributes to the elaboration of prevention programs at schools. This investigation aims to know teachers' social representations, regarding drug abuse, in a secondary school in Florianopolis, SC, Brazil. A total of 16 teachers of the 5th to 8th grades participated in the study. Data were collected through associations elaborated by teachers in response to the expression: drugs use/abuse. The teacher's representations are organized around a central concept - the vulnerable other: a needy adolescent, who becomes drugs user, highlighting the family, everyday coping, and the school's (in)visibility in prevention actions, as factors related. The complexity of factors involving drugs production, distribution and its commercialization, demands the implementation of actions that go beyond the scopes of education and health. The elaboration of inter-sector prevention programs considering local characteristics is necessary.

DESCRIPTORS: substance-related disorders; education, primary and secondary

\section{REPRESENTACIONES SOCIALES SEGÚN LOS PROFESORES AL RESPECTO DEL USO DE DROGAS EN UNA ESCUELA DE EDUCACIÓN BÁSICA}

La preocupación con el abuso de drogas entre los jóvenes obliga a crear estrategias de prevención. El objetivo de esta investigación fue conocer representaciones sociales, según los profesores en una escuela secundaria de Florianópolis respecto al uso de drogas; participaron del estudio 16 profesores del $5^{\circ}$ al $8^{\circ}$ grado de educación secundaria. Las informaciones fueron obtenidas a través de redes de asociaciones, como una forma de respuesta a la expresión estímulo: USO/ABUSO DE DROGAS. Las representaciones mencionadas por los profesores fueron organizadas de acuerdo a un núcleo central -el otro vulnerable - un adolescente con necesidades que se vuelve usuario de drogas; fueron destacados como factores relacionados: la familia, los enfrentamientos en su vida y la poca participación de la escuela en actividades de prevención. La complejidad de los factores involucrados en la producción, distribución y comercialización de drogas exigen la implementación de acciones que sobrepasen el ámbito educativo y de salud. Por lo tanto, son necesarios programas de prevención intersectoriales que sean desarrollados en base a las realidades locales.

DESCRIPTORES: trastornos relacionados con sustancias; educación primária y secundária

\section{REPRESENTAÇÕES SOCIAIS DE PROFESSORES SOBRE O USO DE DROGAS EM UMA ESCOLA DE ENSINO BÁSICO}

A preocupação com o abuso de drogas entre os jovens contribui para a criação de um espaço de prevenção dentro da escola. O objetivo desta investigação é conhecer as representações dos professores de uma escola de ensino básico de Florianópolis sobre o uso de drogas, envolvendo 16 professores de $5^{a}$ a $8^{a}$ séries do ensino básico. As informações foram obtidas através da rede de associações elaborada em resposta à expressão estímulo: USO/ABUSO DE DROGAS. As representações dos professores se organizam em torno de um núcleo central -o outro vulnerável - um adolescente, carente, que se torna usuário de drogas, destacando como fatores relacionados: a família, os enfrentamentos cotidianos e a (in)visibilidade da escola nas ações de prevenção. A complexidade dos fatores envolvidos na produção, distribuição e comercialização de drogas exigem ações que extrapolam o âmbito da educação ou da saúde, sendo necessários programas de prevenção inter-setoriais, envolvendo o estudo das situações locais.

DESCRITORES: transtornos relacionados ao uso de substâncias; educação primária e secundária

${ }^{1}$ PhD, Professor, Santa Catarina Federal University, School of Nursing, Brazil, e-mail: jussara@nfr.ufsc.br; ${ }^{2}$ Full Professor, University of São Paulo at Ribeirão Preto, College of Nursing, WHO Collaborating Centre for Nursing Research Development, Brazil, e-mail: furegato@eerp.usp.br 


\section{INTRODUCTION}

The use of drugs is significant not only because of their typical chemical properties, but also because of their symbolic properties, social imaginary and cultural effect. Drugs make it possible to define social boundaries, to organize different realities surrounding specific rules.

According to the UN World Drug Report, 2005, there are about 200 million drug users in the world and most of them are youths ${ }^{(1)}$. The book "Drogas nas escolas" ("Drugs in schools"), published by UNESCO (United Nations Educational, Scientific and Cultural Organization) at the end of $2002^{(2)}$, had already presented some surveys showing that the use of drugs would increase.

Questionnaires and interviews were applied in public and private junior high ( $5^{\text {th }}$ to $8^{\text {th }}$ grades) and high schools in 14 Brazilian capitals and also in Brasília, the capital of the country, in order to identify how youths understand drugs and what motivates them to use or refuse drugs ${ }^{(3)}$.

The information about drug use forces professionals to face a challenge: is it possible to keep people, especially youths, away from drugs only with school education? That question motivated the search for other information sources, such as teachers' attitudes towards drug use and their participation in educational practices for drug prevention at school. Some differences are expected to exist between total abstinence strategies (never trying alcoholic drinks, for example) and strategies teaching how to use it.

Social representation joins the concept (significance) and the object (significant). The close relation between the subject and the object is shown by understanding what the subject will do with the object, using his/her personal experiences and previous social-group interactions ${ }^{(4)}$.

Thus, each person is surrounded, both individually and collectively, by words, ideas and images which penetrate his/her eyes, ears and mind - even unconsciously. There is always some autonomy and conditioning in the natural, social or even both settings. Classifying and prescribing are the goals of the representations.

The theory of social representations is an important reference for this study, and there is an attempt to build some knowledge considering the close relation between the subject and the representation object, which are mediated by an inter-subjective communicative action.

The goal of this study is to investigate teachers' representations about drug use at a junior high school.

\section{METHODOLOGY}

This is a qualitative and descriptive study and the participants are teachers from a private junior high school in the city of Florianópolis, Santa Catarina, Brazil, founded in 1959 and with a total of 1067 students today.

Data were collected during the first semester of 2006; at the same time, 25 teachers from $5^{\text {th }}$ to $8^{\text {th }}$ grades were invited for a meeting with the researcher. Nineteen professionals were present at the meeting and three of them did not agree to participate in the research. So, sixteen (16) teachers participated in the data collection.

The net of associations was the principal tool to search for information, and it was appropriate to investigate the structure, content and semantic field polarities associated to some representations ${ }^{(5)}$. The net of associations is about including one or more words or "expressions of motivation", which are chosen according to the importance and coherence with other goals of the research, in the middle of a blank piece of paper, followed by guidelines to build the nets. At first, the person must write everything that comes to his/her mind related to the "expression of motivation", which is in the middle of the page; then he/she must number the words following the order they were written in; after that, the person must state the value of each written word in relation to the expression, using "+" for positive, "-" for negative and " 0 " for neutral; at the end, the words must be classified according to their priority in relation to the topic and possible connections must be established.

This study was evaluated and approved by the Committee of Ethics in Research involving Human Beings at Santa Catarina Federal University. The research proposal was presented to the participants and a Term of Consent was read and signed, ensuring compliance with resolution 196 by the National Health Council ${ }^{(6)}$. 


\section{TEACHERS' REPRESENTATIONS ABOUT THE USE/ABUSE OF DRUGS}

The opinions of the teachers from the $5^{\text {th }}$ to $8^{\text {th }}$ grades about the use of drugs are described below. It was an attempt to (un)veil feelings, conflicts, comments and ideologies in those professionals' statements.

The highest rate of preference and the highest priority in the order of the net of associations were used as indicators to define the central nucleus of the teachers' representations.

According to those indicators, teachers' representations are organized based on the concept of "vulnerable person": a subject, mainly a teenager, who has several needs (family, social, personal, psychological and economical), and then becomes a drug user.

In the surrounding nucleus, the teachers mentioned the family, how easy it is to obtain drugs and the lack of public safety actions. Thus, the center of the teachers' representations about drug use states that consumption is something that happens to those who do not know how to behave according to social rules, with inappropriate behavior, multiple needs, but not in their own opinion or according to people who follow the precepts society has established and legitimated.

The teachers created nets of associations with some factors about the difficulties youths have to deal with their strong frustrations in a society where one of the most significant values is "owning" instead of "being". This search for strategies to face reality, which has high levels of frustration, where desire and reality are not fairly related and the consequences are marginalization and exclusion, leads the youths to use drugs, try to escape from the reality and look for pleasure.

Although the teachers who participated in the survey strongly associated the use of drugs with marginalization, it is important to say that some previous studies verified that students from lowerincome community schools consume fewer drugs. According to a 2004 study, multivariate analysis performed in public schools in Campinas (São Paulo) verified that the students from lower-income communities use fewer drugs, despite the existence of more intense drug dealing and higher mortality rates due to violence.

Against expectations, consumption was higher among students from downtown schools and working students, which made the writers associate drug use to financial status. Higher drug consumption among Brazilian students is hypothetically related to stress because of work obligations, and higher financial status is also related to socialization patterns tied to the "working world", such as drinking something at the end of the work day. Such results highlight the need to think about partially-established beliefs, such as spare time being an important factor for drug use $\mathrm{e}^{(7)}$.

One study about the health behavior of young students from public and private schools in the city of São Paulo showed that students from private schools consume substances two to four times more than students from public schools; that fact was verified in the $2^{\text {nd }}$ National Survey, 1989, about the use of psychotropic substances among junior high school and high school students ${ }^{(8)}$.

According to all aspects above, it can be considered that students use drugs for different reasons. Drug use cannot be seen as a result of only one factor. Instead, it results from a mix of several elements, such as genetics, psychological, family, socio-economic and even cultural aspects. Thus, drug use and dependence can be understood as highly complex phenomena, which cannot be reduced to one dimension or attributed to the health system only, because it is a social problem entails consequences for people's health.

The teachers also mentioned that the alcoholic beverage market has not been well controlled because of the amount of advertising and its misleading approach, telling people about the benefits of drinking alcohol.

Brazilian law only allows people who are 18 years or older to buy and drink alcoholic drinks, but the media reaches all ages, advertising beer in charming commercials, while alcohol addicts are rejected and excluded by the same society that encourages consumption. According to the teachers, social behavior confuses the youths and the family, who sometimes may not realize that alcohol and tobacco are also drugs. For them, only illegal substances are drugs.

Neoliberal discourse relates a person's failure or success to his/her individual decisions only, and it can be linked to the rational way the media deals with that issue. Thus, using drugs or not is the responsibility of each person; addicts are not able or mature enough to deal with their problem. 
The relations between society and the use of drugs are not univocal or monolithic ${ }^{(9)}$. The increasing and many times recent repression of illegal drugs use is added to the subtle encouragement to consume legal drugs, such as some medications, which doctors prescribe to have healthy bodies, or self-prescribed drugs for beauty, skills or mood ${ }^{(9)}$.

Repression and encouragement of drug consumption is the same as considering drugs a criminal-medical problem. Medical-legal dispositions about the issue characterize a kind of "drug provision" that is very similar to Foucault's sexuality provision.

Besides having adopted drug use experiences, present societies literally created the drug phenomenon itself in two ways: body medication and criminal use of substances which were not considered drugs until their prescription and destitution $^{(9)}$. That process includes legal intervention in the drug world, characterized by efforts to classify drugs, creation of special places to treat users, police repression against drug dealing or illegal drug market, and also the enlargement and specialization of police work areas and interventions in the "drug world", in control and medication places and places were drugs are provided. These themes go beyond the comprehension of this study.

In everyday life, because of the health of the body, the consumption of medication is fought, but the consumption of drugs as medication is encouraged; hence, there is one kind of consumption that is allowed and another one that is not; one kind of consumption that is morally qualified and another that is disqualified $^{(9)}$.

In this study, the teachers ratify that they understand that the experiences of using substances known as "drugs" are an invention of the modern western society when considering their distribution and consumption; they reached that point by considering only illegal drugs and relating the substances to personal needs and difficulties to face daily conflicts by people who are illegal drug users. In societies with the same kind of power as ours, the use of drugs and the Medicine Science have ambiguous relationships, prescribing and controlling some drugs which are considered good for health and disqualifying others that are not prescribed or controlled. In this way, the doctors take care of two different groups of drug addicts: prescribing drugs that cause dependence for one group and treating people who intoxicate themselves in another group.
When analyzing drug use, it is important to consider how human beings' social, material or symbolic production happens; and also, conceptions of life and death and the experiences involved ${ }^{(9)}$.

Maybe the relation between everyday conflicts and the use of drugs the teachers presented in their representations can be understood by addressing primitive and modern western conditions of drug consumption.

The goal of a discussion about a wide set of explanatory questions about the drug phenomenon is to highlight the challenges in order to understand the problem and to perform actions to reinforce the responsibility of the community, as well as the complexity of the theme.

The mix of emotional relations and power is another important factor for the teachers; this is how society has been creating and confirming power relations and different ways to value emotions, feelings and life. Thus, the value system causes frustration, dissatisfaction and unhappiness in people, especially in youths who think they are outside society and excluded from different nets of consumption; it is difficult for them to notice that there are other ways of insertion and self-recognition, especially because the search for power by consumption is most emphasized. It is as if citizenship depends on the classification of the "consumers", that is, the best citizens are those who consume more.

In the teachers' opinion, the "deterioration" of human values and society's "dehumanization" are related to the use of drugs, and prevention must be based on interdisciplinary and intersectional knowledge.

However, preventive actions must allow adolescents to think and contemplate their lives, choices, desires, frustrations and future in a critical and conscious way. Preventive actions must do more than simply forbid.

Only two teachers mentioned that schools must help to prevent the use of drugs. That fact can be disquieting, because a study with students, teachers and parents performed at junior high schools in fourteen Brazilian capitals showed that $23.1 \%$ of the students, $10.8 \%$ of members from technicalpedagogical boards and $3.4 \%$ of parents stated that they have already seen drugs at school ${ }^{(3)}$.

In history, society has appointed schools as privileged places where drug use is prevented. There have been some modifications in preventive practices. This evolution is followed by a much more including 
strategy and a much wider base to prevent drugs and violence. Family, community and schools must fight drugs in the country so that all that effort can be effective.

In general, teachers are becoming more alert about those issues. They are more conscious about the relationship between the consumption of drugs and education, teaching and learning. That is an important fact for health.

Dr. Robert Du Pont, former director of the National Institute of Drug Abuse in the United States provided the following guidelines to parents in order to contribute to parent and child relationships ${ }^{(10)}$ :

1. Establish a family agreement about the use of substances;

2. Establish kinds of punishment for not following the rules;

3. Dedicate some time during the day to talk to children about their lives, how they feel and what they think;

4. Help children to establish their personal goals;

5. Meet the children's friends;

6. Help the children to feel well with their own qualities and their small or big successes;

7. There should be an established system to solve conflicts;

8. As soon as possible, and often, talk to the children about their future;

9. Enjoy the children;

10. Be a "nosy" parent.

The role of the school is to reinforce the guidelines above. There are things that schools can and must do, and it is important to establish connected actions.

Connectivity means a better connection between youths and adults through orientation programs, with fewer students in the classroom, so that teachers can clearly recognize all the students in there, or having small schools where everybody is known by name and children and adolescents have the opportunity to talk and live their feelings and emotions, practice sports, be in touch with arts and the academic side of things. Another solution could include teachers professionally skilled to notice that the students are confused and/or taking drugs, and then interact with this situation.

Prevention is not only having a one-hour program at school a week, with an invited lecturer, during 15 or 20 weeks; it is a lifestyle; it is a permanent and strategic process. Prevention should start early and permeate everything that is done along the school year.
When some possibilities of bringing the school and the community together to prevent the use of drugs are examined, it is very important to think about at least four principles:

- Schools need to develop continuous evaluations of their problems;

- Students and the community should participate when establishing aims and goals;

- Use cooperative prevention programs, together with universities, state departments of education and private companies;

- Evaluate the process, which helps to improve the developed activities and propose new intervention modalities.

Preventing drugs is not a "magic" issue that one department or society institution can solve independently. It is essential for the problem to be considered "our problem", not "their problem". That is why it is disquieting not to find the school or the teacher in the net of associations created by the teachers in this study. But there are optimistic perspectives about the future anyway.

There is an increasing number of schools analyzing the issue, and they are interested in facing that problem, using comprehensive perspectives with a very wide base. The program "Lineamientos Hemisféricos de la CICAD en Prevención Escolar", created and published by the Inter-American Drug Abuse Control Commission (CICAD) includes investigation, creation of educational material, qualifying teachers, performance and the evaluation of national, regional and international programs within the American states $^{(11)}$.

\section{FINAL CONSIDERATIONS}

The study about teachers' social representations about drugs use in a private junior high school in Florianópolis, under specific cultural and historical conditions, showed that the teachers consider that the use of drugs is a problem in vulnerable adolescents.

That vulnerability was considered a negative issue and the first concept to appear for the participants. The way such issues appear in association nets characterizes the use of drugs as a kind of "fault" of the user him/herself in a process called "failure of the victim itself", where the subject is responsible for all situations in his/her life. 
The association nets the teachers created repeat a dualistic comprehension about drugs: good and evil. That is a simple conception, which can be a problem when facing such a complex issue with regard to drugs use/. It is necessary to do more than simply education or health actions, because of the complexity of the factors in drug production, distribution and sales; intersectional prevention programs are also necessary.

It is possible that the goal of educational practice is to make the youths think about their lives in a critical way. There are no single models, formulas or methodologies to approach the use of drugs at school. On the contrary: all the characteristics of the school community need to be considered, as well as the differences among the youths and drug users, and also the kind of drug more commonly available in the regional and local contexts. Therefore, it is necessary to discuss the characteristics and reality of prevention practices and create longer-lasting approaches in order to get better results.

This is an initial, partial and limited picture for the teachers who have participated in this study.

\section{REFERENCES}

1. Organização das Nações Unidas. Relatório Mundial sobre Drogas 2005. [ acesso em 2006 Maio 07]. Disponível em www.onu.org

2. Organização das Nações Unidas para a Educação, a Ciência e a Cultura. Pesquisa sobre drogas e Juventude [acesso em 2005 Jul 29]. Disponível em: http:// observatorio.ucb.unesco.org.br/publicacoes/drogas

3. Abramovay M, Castro MG. Drogas nas escolas. Brasília: UNESCO; 2002.

4. Rangel Mary. A representação social como opção teóricometodológica para a produção do conhecimento em didática. Caxambu: ANPED; 1993.

5. Rosa AS. Le "réseau d'associations" comme méthode d'étude dans la recherché sur les representations socials: structure, contenus et polarité du champ sémantique. Cahiers Internat. Psychol. Soc. 1995; 4(28):95-122.

6. Ministério da Saúde (BR). Diretrizes e normas regulamentadoras de pesquisa com seres humanos. Brasília (DF): Ministério da Saúde; 1997.
However, it is necessary to develop teachers' skills to address the issues of drugs use/abuse in junior high school, since it reinforces the important role of the school in prevention.

\section{ACKNOWLEDGEMENTS}

Acknowledgements to the Inter-American Drug Abuse Control Commission/CICAD of the SubSecretary of Multidimensional Security at the Organization of American States/OAS, the Brazilian Anti-Drugs Secretary/SENAD, faculty members at the University of São Paulo at Ribeirão Preto College of Nursing, WHO Collaborating Centre for Nursing Research Development, Brazil, to the population who participated in the studies and to the representatives from eight Latin-American countries who participated in the I and II On-Line Specialization Program for Research Capacity-Building on the Drugs Phenomenon-PREINVEST, offered in 2005/2006 by the University of São Paulo at Ribeirão Preto College of Nursing, as a distance education course.
7. Soldera M, Dalgalarrondo HRCF, Silva CAM. Uso de drogas psicotrópicas por estudantes: prevalência e fatores associados. Rev. Saúde Públ. 2004; 38(2):277-83.

8. Carlini-Cotrim B, Gazal-Carvalho C, Gouveia N. Comportamentos de saúde entre jovens estudantes das redes pública e privada da área metropolitana do Estado de São Paulo. Rev. Saúde Pub. 2000; 34(6):636-45 [acesso em 2006 Maio 05]. Disponível em www.usp.br/rps.

9. Vargas EV. Os corpos intensivos: sobre o estatuto social do consumo de drogas legais e ilegais. In: Duarte LFD, Leal OF, organização. Doença, sofrimento, perturbação: perspectivas etnográficas. Rio de Janeiro: Fiocruz; 1998. p. 121-36.

10. Silber TJ, Souza RP. Uso e abuso de drogas na adolescência: o que se deve e o que se pode fazer. Adolesc. Latinoam. 19981 (3): [acesso em 2006 Maio 05]. Disponível em: www.ral-adolesc.bvs.br/scielo

11. Organización de los Estados Americanos, Comisión Interamericana para el Control del Abuso de Drogas. Lineamentos Hemisféricos de la CICAD en prevención escolar. Washington; 2005. [acesso em 2006 Maio 05]. Disponible em http:// www.cicad.oea.org. 